\title{
Melodramat jako gatunek „przepisany” (na przykładzie XIX-wiecznych dramatów inspirowanych dziełami Hugo, Mickiewicza, Scotta)
}

Wśród licznych strategii intertekstualnych rewriting wyróżnia się, jak zauważa Steven Connor (Connor: 80), przede wszystkim tym, że zakłada szczegółowy i ścisły związek z pojedynczym, konkretnym tekstowym poprzednikiem. Konsekwencją zastosowania poetyki przepisywania jest uwikłanie „powtórzonego", przetworzonego utworu literackiego w nieustającą walkę między własną tożsamością, domniemanym „nowatorstwem” a tym, co moglibyśmy śmiało określić jako arché pierwowzoru. W trakcie przepisywania ulec zmianie może praktycznie każda cecha oryginału lub przeciwnie, zmiany mogą być znikome. Co istotne, modyfikacje te mogą zachodzić na kilku płaszczyznach i dotyczą nierzadko w większym stopniu ideologii niż tylko poetyki pierwowzoru. W tym sensie przepisywane dzieło stanowi reinterpretację tekstu-matki, włączając go tym samym w obszar intertekstualnych gier z tradycją. Wypada dodatkowo podkreślić, że dwa z trzech poddanych analizie tekstów są nie tylko przekładem intersemiotycznym bestsellerowych powieści na spektakl teatralny, jednocześnie mieszczą się w zaproponowanej przez André Lefevere’a koncepcji tłumaczenia jako jednej z form przepisywania, za pomocą którego dokonuje się przenikanie tekstów z jednej kultury do drugiej. Sytuację komplikuje dodatkowo fakt, że obcujemy z dziełami adaptowanymi do wystawienia na scenie, a jak zaznacza 
już w samym tytule artykułu Małgorzata Leyko (Leyko: 77), teatr to sztuka „(systemowego) przepisywania”. Praktyka sceniczna jawi się jako w najwyższym stopniu uwikłana w ten proceder nieomal od początku swojego istnienia, w przypadku tekstów osiemnasto-, dziewiętnastowiecznych wystarczy wspomnieć choćby praktykę „adaptowanego przekładu”, dostarczającą „naprędce” repertuaru świeżo otwartemu Teatrowi Narodowemu.

Sam melodramat jako gatunek teatralny już od chwili swoich narodzin jawi się jako forma eklektyczna, mozaikowa, posługująca się z ogromną swobodą środkami wyrazu artystycznego pochodzącymi z całkowicie odrębnych, niejednokrotnie sprzecznych estetyk. Śmiało miesza komizm z tragizmem, pantomimę ze słowem. Dobrochna Ratajczakowa podkreśla, że właściwie jest on „serią gatunków granicznych, [...] »dzieckiem« Diderotowskiej koncepcji dramy mieszczańskiej, [...] lecz również idei Diderota scenicznego tableau, otwierającego drogę do wielkiego spektaklu” (Ratajczakowa: 219) W skład owego szczególnego produktu weszły gatunki poprzedzające, nie tylko przyczyniając się do jego powstania, ale przede wszystkim obiecując autorom satysfakcję wypływającą z succès d'estime, który gwarantowało spełnienie różnych, niejednokrotnie skrajnie odmiennych oczekiwań publiczności. Sprawą podobnie kłopotliwą jak genologia melodramatów okazuje się również kwestia ich atrybucji. Autorstwo dzieł wystawianych na scenie stanowiło od dawna kwestię płynną i względną. Dotyczy to zarówno wersji oryginalnych, „kanonicznych”, których teatr - jako takich - w ogóle nie zna, jeśli autor tekstu nie jest zarazem twórcą przedstawienia. Sprawę komplikuje dodatkowo obfitość produkcji literackiej. Liczni dramatopisarze pierwszego, a częściej drugiego i trzeciego rzędu, próbowali swych sił w gatunku popularnym, modnym, o oczywistym zapotrzebowaniu, a przy tym szczególnie nieskrępowanym regułami czy normami. Na melodramat „przepisywano” inne gatunki - powieści, ballady, tragedie, historie tragiczne. Powstające wskutek takiej ingerencji dramaty zachowywały co prawda główne założenie fabularne oryginału, lecz w kształcie przypominały go jedynie w ogólnych zarysach.

W początkach krystalizowania i dalszej historii gatunku melodramat najsilniej związany był z powieścią - gotycką, romantyczną, realistyczną. Adaptowanie powieści wiązało się nieuchronnie z przenoszeniem do teatru epickiej struktury fabuły. W wypadku form przepisanych szczególnie interesujące 
wydają się pominięcia, przestawienia, uproszczenia powiązane niejednokrotnie z całkowitą zmianą sensu oryginału. $Z$ antycznej fabuły tragicznej zachowano zasadę nieuchronności katastrofy, która nie pochodzi od sił transcendentalnych, ale od innych ludzi. W wybranych do analizy tekstach autorzy adaptacji sięgali po dzieła epatujące typowym rekwizytorium czarnoromantycznym, na który składają się przestrzenie ewokujące tajemnicę (zamek, grób, ruina, cmentarz, las, dzika okolica, gotycka katedra), nastrój pustki, smutku, grozy, melancholii, demonicznego, irracjonalnego zagrożenia. Najczęściej rezygnowali oni przy tym z trudniejszej formy wierszowanej na rzecz prozy, zachowując jednak relikt po pantomimie heroicznej, tableau, w jego odmianie malowniczej i idyllicznej.

Charakterystyczne dla melodramatu elementy odnaleźć można już w starożytności, w tragediach greckich, wspomnę choćby o przepowiedniach, dramatycznych ucieczkach z rąk prześladowców, sensacyjnych rozpoznaniach tożsamości bohaterów, rodzicach celowo krzywdzących swoje dzieci. Najsilniejsze jednak piętno wywarła na nim powieść sentymentalna i charakterystyczna dla niej predylekcja do obfitego prezentowania i wyznawania uczyć. Jak słusznie zauważa Anna Martuszewska, określone w niej i często określone imionami bohaterek Richardsona schematy fabularne na najbliższe dwa stulecia będą organizowały przeważającą większość fabuł romansowych (Martuszewska: 39). Melodramat wszakże, „zapożyczając się” nieomalże od wszystkich, wypracował własne środki wyrazu scenicznego, polegające na złożeniu artystycznego przekazu z wielu form: muzyki, tańca, monologu, a nade wszystko ekspresji scenicznej postaci. W strukturze samego gatunku teatralnego na stałe zadomowiły się takie zabiegi i chwyty, jak nagłe zwroty akcji, zaskoczenie, mieszanie komiki niskiej z uwznioślającym patosem, występowanie kontrastowo ujętych postaci, ich hiperboliczne gesty. W sensie alegorycznym melodramat stał się najlepszą z możliwych kulturową odpowiedzią na świat zatracający swoje podstawy i stabilność po Wielkiej Rewolucji; siłą sprawczą dramatu jest złoczyńca, „czarny charakter”, za jego pośrednictwem działają ciemne siły chaosu i destrukcji.

W melodramacie Oblubienica z Lammermoor, ,naśladowanym z romansu Waltera Scotta” przez Victora Ducange'a (1832), najpoważniejsza zmiana dotyczy struktury zakończenia. Wynika ono logicznie ze sposobu, w jaki poprowadzono charakterystykę bohaterów, ale jest całkowicie odmienne od pierwowzoru. Otóż w ostatniej scenie narzeczeni, Edgar i Łucja, świadomie 
decydują się na śmierć samobójczą w zburzonych odmętach morskich. Ta daleko idąca modyfikacja całkowicie eliminuje potencjalnie atrakcyjną scenę obłędu Łucji mordującej w kataleptycznym transie swego niedoszłego męża, a następnie umierającej bezprzytomnie w konwulsjach. Decyzja o rezygnacji z tych nasyconych patosem fragmentów powieści, de facto „gotowych” do przeniesienia na deski sceniczne bez jakichkolwiek retuszów czy skreśleń, wydawałaby się co najmniej zastanawiająca (wszak ekspresywna gestyka postaci odzwierciedla metaforycznie istotę całego wszechświata, który jest dynamiczny, oparty na agonie), gdyby nie wyraźne inspiracje sentymentalizmem. Przejawiają się one w kilku planach melodramatu: charakterystyce protagonistów, kreacji przestrzeni scenicznej, wreszcie - w stereotypizacji gestów i zachowań postaci (damy z chusteczką przy oczach, słaniające się na krzesła w omdleniu, podtrzymywane przez młodzieńców o dzikim wejrzeniu, niepohamowanych i gwałtownych tak w mowie, jak i w ruchach). W wypadku adaptacji Ducange'a obserwujemy, jak autor redefiniuje pojęcia grozy, wzniosłości, tragizmu czy patosu, doprowadzając do dominacji elementów, które z czasem w jego twórczości przeznaczonej na scenę ulegną popularyzacji, nawet trywializacji. Krytycy teatralni, zwłaszcza postulujący „zwrot klasycystyczny”, jak choćby Euzebiusz Słowacki czy Jędrzej Śniadecki, tłumaczą tę dręczącą powtarzalność i w efekcie banalizację treści hołdowaniem najniższym instynktom publiczności. W ich interpretacji, gdy grany jest ów rodzaj sztuk „zły i zamiarom sceny przeciwny” (Słowacki: 13), w lożach witany jest kpiną, na paradyzie - westchnieniem wzruszenia i łzą.

W melodramacie wkraczamy w sytuację miłosną in medias res; kiedy poznajemy przyszłych narzeczonych, doszło już do ich przypadkowego spotkania. Uczucie łączące dwoje kochanków zostało uwznioślone - przede wszystkim w obrazie śmierci traktowanej jako mistyczne zaślubiny. Także sami bohaterowie nakreśleni zostali zgoła odmiennie niż w prototypie. Westchnienia, omdlenia, wylewanie potoków łez, ów zdawałoby się nieco anachroniczny sztafaż sentymentalny, okazuje się przedziwnie trwały i nie jest to jedyny spadek po mijającej epoce. Wspólnym mianownikiem późnooświeceniowych dram i melodramatów jest specyficzna konstrukcja fabularna, jako współcześni czytelnicy odnosimy nieodparte wrażenie, że ich intrygę, w zasadniczym zrębie, ułożył jeszcze Richardson, charaktery natomiast są własnością Jana Jakuba. W melodramatycznej przeróbce Łucja, jakby za przykładem Roussowskiej Julii, 
wydaje się poświęcać całą swoją uwagę partnerowi, jest raczej tkliwa i pełna litości dla cierpień miłosnych partnera niż roznamiętniona. Czuła, cnotliwa, niewinna i... pasywna, stanowi idealne wcielenie bohaterki sentymentalnej. Jedynym, jakże fatalnym, przejawem samodzielności bohaterki jest zakochanie się w przypadkowo spotkanym młodzieńcu. Smutek widoczny na jego obliczu jest dla dziewczyny jawnym świadectwem duchowej głębi: „Chroni się zwykle przed wszystkimi, zdaje się czegoś obawiać... można by sądzić, że jakieś wielkie nieszczęście go obarcza” (Ducange: 19) Jej wybranek także całkowicie odbiega od swojego powieściowego pierwowzoru, przypominającego w wielu zarysach typ zagadkowego, gotyckiego łotra. Po przodkach Scottowski Edgar odziedziczył dumę, gwałtowność, brak rozwagi, mściwość i zawiść, a wspomniane cechy i afekty zaledwie udaje mu się powściągnąć, i to tylko pod wpływem świeżo zrodzonego uczucia. Natomiast Łucja nudzi się, jest samotna i ciekawa świata znanego jej z lektury romansów rycerskich. Emocjonalność Edgara napawa ją pierwotnym lękiem. Dziewczyna ma zresztą świadomość, że sama ściągnęła na siebie nieszczęście, bo jej ukochany wydaje się obciążony przekleństwem. Edgar w melodramacie Ducange’a jest postacią spłyconą, zaprzepaszczona została potencja wewnętrznej walki, dynamiki tej postaci. Oglądamy jednostkę bezdyskusyjnie szlachetną, istnego ostatniego tragarza tradycji rycerskiej; naiwnie się kocha, dość łatwo porzuca myśl o kontynuowaniu waśni rodowej, zasłania własną piersią osobę, co do której powziął uprzednio nienawistne uczucia. W melodramacie, porównując dwie główne postaci, scenicznie „wygraną” jest Łucja. W wypadku Edgara Ducange zdjął ze swojego bohatera odium dwuznaczności, „romantyczności”, rodowej klątwy, osamotnienia, immanentnego tragizmu tej postaci. Widzowie zapamiętają go jako jednostkę nieskazitelną, szlachetną, rycerską bez skazy, w najtrudniejszych bodaj okolicznościach organicznie niezdolną do uchybienia anachronicznie rozumianej zasadzie honoru.

Autor melodramatu zręcznie wykorzystuje motywy obecne w powieści, co więcej, multiplikuje je, w rezultacie Edgar ratuje życie Łucji i jej ojca nie raz, ale dwa razy. W powieści bohater, ocalając ich przed szarżą rozjuszonego byka nie wie, że pomaga człowiekowi, z którym wiąże go waśń rodowa, obydwoje zasłania własnym ciałem. Melodramat przynosi istotną modyfikację w stosunku do oryginału, gdzie amant ratuje zagrożone osoby niejako przypadkiem, wykazuje się celnością strzału i postąpiłby analogicznie w wypadku dowolnej osoby 
w podobnej sytuacji. Scena drugiego ratunku Łucji i jej ojca jest powiązana z ich pobytem w wieży Ravenswood. U Scotta gospodarz domu przychodzi z pomocą osobom, które chronią się przed burzą, w melodramacie wspomniana scena zostaje znacząco rozbudowana. Edgar musi oprzeć się pokusie dokonania zemsty na odwiecznym wrogu, do której obliguje go wierność przysiędze złożonej konającemu ojcu na łożu śmierci. Główny bohater nie tylko posunie się do takiego działania, gdy stanie sam na sam ze swoim wrogiem, uczyni więcej - zasłoni go własną piersią, gdy wieżę szturmować będą polityczni przeciwnicy Lorda i wynajęci skrytobójcy. Edgar Ducange’a jest wrażliwy, egzaltowany i szlachetny, dlatego pada ofiarą cynicznych manipulacji politycznych swojego kuzyna margrabiego d'Athol. To margrabia, jako makiaweliczny łotr, pozostając w przestrzeni imaginacyjnej, odpowiada za ruinę finansową rodu Ravenswooda, poróżnienie Edgara z Lordem Ashton, ojcem Łucji, oskarżenie tegoż o przestępstwo, które popełnił d'Athol, próbę namówienia Edgara na skrytobójczy mord Ashtona, wreszcie - wydanie rozkazu uwięzienia i stracenia młodego Ravenswooda. Istotną zmianą w porównaniu z powieścią jest znalezienie scenicznego odpowiednika łotra w osobie macochy Łucji i brata Lady Ashton, Lorda Douglasa. U Scotta wcieleniem zła jest rodzona matka bohaterki, która z pełną świadomością wpędza niekochaną córkę w obłęd przy pomocy sprowadzonej do zamku czarownicy. W przeróbce Ducange’a wspomniana postać, mimo jej niebanalnej potencji demonicznej, nie przekonuje, jest pozbawiona nerwu dramatycznego, autor melodramatu nie pozostawił jej miejsca na to, „by się rozegrać”.

W rozprawie Petera Brooksa, The Melodramatic Imagination: Balzac, Henry James. Melodrama and the Mode of Excess (Brooks, 1995), rozpatrująca melodramatyzm jako kategorię estetyczną, pewien typ wyobraźni, autor kładzie nacisk na wspomniane uprzednio tableau, moment, w którym działanie postaci zostaje „zamrożone”. Działanie tej zasady obserwujemy w adaptacji Ducange’a, z całą pewnością mamy tu do czynienia z próbą przejścia od dramatu w aktach do dramatu w obrazach. Szybko następujące po sobie dynamiczne sceny - Edgar ratujący Łucję i jej ojca przed rozszalałym bykiem, następnie przed zabójcami szturmującymi wieżę, mdlejąca Łucja rzucająca się w objęcia najbliższych, by ich chronić - składają się w sekwencję: ratunek przez osłonięcie własnym ciałem pointowany koniecznym omdleniem bohaterki. W efekcie oglądamy cztery, czy raczej dwa, powtórzone żywe obrazy niezłomnego wybawiciela 
Edgara i mężnej, acz omdlewającej Łucji, i to jeszcze zanim naszą uwagę zajmą imponujące sceny finałowe.

Uproszczenie Scottowskiej formuły powieściowej - w melodramacie mamy do czynienia z tragizmem „niskim” i zewnętrznym, ukazującym niemoc ofiar w obliczu knowań ludzi podążających ślepo za siłą najniższych instynktów, powodowanych chciwością czy pragnieniem władzy - dynamizuje bieg akcji, pointowanej w stosownych odstępach wstrząsającym żywym obrazem. W powieści koincydencje zdarzeń prowadzące w efekcie do spektakularnej tragedii kochanków są niezwykle skomplikowane, uwikłane w ludowe wierzenia szkockie, w specyfikę życia religijnego tego okresu, zmagania stronnictw politycznych rywalizujących zwolenników Wilhelma Orańskiego i Jakuba II. Ducange o jakże ważnym aspekcie historycznym wspomina incydentalnie, nie wykorzystuje wątku odmiennego wyznania jako przeszkody do połączenia kochanków, skupia się na podkreśleniu szlachetności Edgara, który - hołdując starożytnemu prawu gościnności - nie zaatakuje domniemanego wroga pod własnym dachem. W melodramacie zawiłości polityczne $\mathrm{w}$ istocie zdają się przeszkodą w spójności akcji, autor nie panuje nad tym żywiołem, po trosze upraszcza ten wątek, po trosze go niekonsekwentnie modyfikuje, pozostawiając wrażenie chaosu. Lady Ashton pod piórem Ducange’a ulega przekształceniu w banalny typ złej macochy, tracąc przy tym na głębi wyrazu; wszakże w oryginale była konsekwentnie zestawiana z Szekspirowską Lady Makbet jako istota na wpół demoniczna. Jej melodramatyczna inkarnacja okazuje się więcej niż stereotypowa. Zawiłości polityczne stające na przeszkodzie finalnemu połączeniu bohaterów rozwikłać można jedynie, a i to nie do końca, przy skrupulatnej lekturze sztuki, niespójne niuanse umkną uwadze nawet osobom obeznanym ze Scottowskim pierwowzorem. Wydaje się, że nie jest to wadą omawianej adaptacji, przeciwnie, hipotetycznie rzecz ujmując, konsekwentnie przeprowadzona elizja wspomnianych wątków, w logice sceny całkowicie pobocznych, „oczyściłaby” melodramat ze składników niekoniecznych, działając na korzyść wyrazistości i dynamiki akcji.

Ducange niezwykle konsekwentnie eliminuje w adaptacji scenicznej elementy złowróżbnych przeczuć, obrzędów o charakterze magicznym, fatalnych znaków (zabity kruk plamiący krwią suknię Łucji, zjawa, przepowiednie ślepej wieszczki, ingerencja czarownicy, ciążące nad rodem przekleństwo, przełamana 
moneta). Zapożyczone z powieści rozwiązania, replikowane w melodramacie, nie zostają pogłębione symbolicznie. Jako przykład może posłużyć scena ocalenia Łucji i jej ojca przed dzikim zwierzęciem. Szarżujący na bohaterkę byk znajduje się w herbie Edgara, narzucająca się w tym wypadku interpretacja podpowiada, że wściekły zwierz jest metaforą nieokiełznanych namiętności hrabiego, które w finale doprowadzą do tragicznej śmierci narzeczonej i jego samego. W melodramacie wspomniana scena nosi na sobie nieścieralne piętno sentymentalizmu, podobnie rozwiązana zostaje scena przy fontannie - bohater ocala, bohaterka mdleje. W powieści źródło jest miejscem pierwszego kontaktu, dotyku, spojrzenia; w chwili, gdy Łucja odzyskuje świadomość, zakochuje się od pierwszego wejrzenia w nieznajomym zwilżającym wodą jej skronie. Czytelnik Scotta zaś uprzednio został wprowadzony w temat klątwy, jaka wiąże to źródło, ród Ravenwood i powiązane z nim kobiety; przyszli kochankowie poznali się i zapałali uczuciem w miejscu fatalnym, co determinuje wyłącznie tragiczne rozwiązania i wybory. W wypadku adaptacji Ducange’a zostają zachowane zręby fabuły, ale dalszy rozwój akcji melodramatu w żadnej mierze nie usprawiedliwia wierności oryginałowi. Co prawda kochankowie wymieniają pierścienie przy odpowiedniku Źródła Boginki, nazwanego tu Fontanną Syreny (?), widzowie nie dowiedzą się jednak, że to miejsce jest obciążone klątwą związaną z niewinnie przelaną krwią dziewczyny - nimfy, która pochopnie obdarzyła miłością mężczyznę z rodu Ravenswood.

Co jednak symptomatyczne, wszystkie malownicze miejsca akcji zostają „ocalone w tłumaczeniu”, przy tym niezwykle starannie zaaranżowane i opisane w didaskaliach. W przestrzeni przedstawionej, nie imaginacyjnej, oglądamy rodową wieżę Wolfcrag, o którą biją morskie fale, majaczącą w blasku księżyca niczym okryta całunem gigantyczna zjawa - to miejsce spoczynku ojca Edgara, sceniczny znak śmierci - wkomponowaną w pejzaż o określonej dyspozycji semantycznej. Zrujnowana budowla, przypominająca symbol z kart tarota, ewokuje nastrój niezmiennej, beznadziejnej melancholii zaprawionej grozą:

[...] ruiny, kiedy niekiedy blaskiem oświecone, pomiędzy tymi zwaliskami [...] daje się spostrzegać wydrążenie w podobieństwie nagrobka, który powinien być ciągle oświecony, to światło jednak nie oświeca innych przyległych części sceny, ale przeciwnie, tworzy znaczny odcień.

(Ducange: 22) 
Obraz wyraźnie wyodrębnionej wnęki grobowej, zetlałe tkaniny, walające się potrzaskane meble, pobite naczynia, pozostałości po zakończonej waśnią rodową stypie, disiecta membra dawnego bogactwa i świetności, zyskuje kontynuację w scenie burzy. W strzelistą wieżę walą pioruny, ma miejsce szturm wrogów Edgara, chwilowo odparty, następnie wybucha pożar, Wolfcrag płonie, zamek przejęli uprzednio Ashtonowie, wrogowie rodu Ravenswoodów. Główny bohater nie ma już żadnego miejsca na ziemi, które mógłby nazwać własnym. Tej roli, w adaptacji Ducange’a, nie spełni nawet grób, na tej ziemi miał go nie będzie, jego ciało, inaczej niż ciało kochanki, pochłoną morskie odmęty. Wspomniane dwie sceny, finałową i szturmu wieży, zaliczyć należy do potencjalnie „najsilniejszych” partii sztuki, a przy tym do fragmentów adaptacji najlepiej oddających charakter pierwowzoru.

W adaptacji Ducange’a perspektywę odbioru determinują liczne zapowiedzi śmierci, tak jak w klasycznym romansie sentymentalnym pojawiają się one w deklaracjach „przesłodzonych” bohaterów, zaklęciach i przysięgach, języku miłosnych zachwytów. W melodramacie Ducange’a narzeczeni świadomie dążą do śmierci, prowokują niebezpieczne sytuacje, drażnią słowami:

Odpowiedz mu, że umrę wierną dla niego! (Ducange: 88)

Wystawiam się na śmierć, wiem o tem... Ale wiedzcie, że jestem w rozpaczy!... i że nie dbam o życie. (Ducange: 106)

Edgarze! Nie mogąc żyć z sobą, umierajmy razem! (Ducange: 117)

Łucja inicjuje samobójstwo, prowokując narzeczonego, by za nią podążył. Bohaterka nieco wcześniej dość nieporadnie usiłuje wyrazić szarpiące nią emocje: „Umysł tępieje... serce zlodowaciało... moja głowa płonie... już nic nie widzę...” (Ducange: 93). Tragizm losu bohaterów powieści Scotta potęguje fakt, że do końca próbują śmierci uniknąć. Jedną z modyfikacji pierwowzoru $\mathrm{w}$ duchu sentymentalnym jest wprowadzenie wątku wiernego sługi, starca, który padając na kolana, daremnie błaga o darowanie życia jego panu za cenę rezygnacji z narzeczonej i opuszczenia na zawsze Szkocji. W powieści niestabilna psychicznie Scottowska bohaterka, obserwując przygotowania do ślubu, na chwilę się ożywia, bawią ją suknie i fatałaszki, katastrofę wywołuje nieoczekiwane przybycie Edgara. Natomiast w melodramacie Ducange'a ostatnie sceny, 
wyjąwszy finałową, trudno zaliczyć do przekonujących, tak aktorsko, jak psychologicznie i scenicznie. Łucja nieomal cały czas pozbawiona przytomności jest wleczona w różne miejsca i w somnambulicznym transie konfrontowana z różnymi niewystępującymi dotąd w sztuce osobami, to pastorem, to znów niedoszłym mężem. W wyniku szarpaniny „rozwodzi ją” macocha, zwlekając jej z szyi pierścień, zakład przysiężonej wiary. Melodramat w istocie niezwykle traci w porównaniu z wersją Scotta, gdzie narzeczona z Lammermoor powoli pogrąża się w obłędzie, wcześnie wykazując pierwsze oznaki szaleństwa. Z drugiej jednak strony zachowuje szczątki świadomości, pół-świadomości, kontrakt małżeński podpisuje pustym piórem, sama, acz niechętnie, oddaje Edgarowi nadłamaną monetę. Inaczej wypada ocenić bohaterkę Ducange’a - melodramatyczna Łucja świadomie postanawia poświęcić swoje życie, by ocalić zagrożonego aresztowaniem i śmiercią ukochanego, sama składa się w ofierze na ołtarzu miłości. Jest niewinną ofiarą, najbliżsi wykorzystali ją i zawiedli jej zaufanie; składając przyrzeczenie, sądziła, że może liczyć na przychylność ojca. Wspomniana postać ma u Ducange’a słabą dyspozycję dramatyczną, autor poprowadził ją niekonsekwentnie, w efekcie odbiorcom trudno wnioskować, czy oglądają postać złą, czy skrajnie chwiejną, słabą. Tych dylematów są pozbawieni czytelnicy Scotta. Gdy do akcji wkracza Lady Ashton, widzimy, że jej mąż jest ślepą marionetką dzierżoną żelazną dłonią. W powieści główna bohaterka ma przebłysk świadomości, że zawiniła, podjęła decyzję pochopną i przedwczesną: „Tak bydź musi; sama nie radząc się nikogo, rzuciłam się w przepaść, muszę sama bez niczyiey porady wydostać się z niey lub umrzeć" (Scott: 134). Łucja Ducange’a jest konsekwentnie rysowana „grubą”, nawet jak na warunki melodramatu, kreską, w jej postaci nie dopatrzymy się żadnych pogłębień ani pęknięć.

Własnym pomysłem autora melodramatu są idylliczne scenki w typie przędących kobiet, niewinnych rozmów toczonych w leśnej chatce ślepej piastunki, dziewcząt splatających wianki i śpiewających pieśni obrzędowe na wyprowadzenie narzeczonej, czy zaręczyn o wschodzie słońca w parku Lammermoor w otoczeniu bajecznych klombów kwiatów i drzew. Wydaje się, że wspomniane sceny należy czytać jako ukłon w kierunku wyobraźni sentymentalnej. Świat melodramatu ma naturę metaforyczną, co znamionuje kosmiczny dualizm nocy i dnia, zła i dobra, księżyca i słońca, tajemnicy i wiedzy. Wysoka i strzelista wieża spłonie (żar namiętności), runie (upadek rodu), bohaterowie 
skoczą ze skały w morze (odmęty jako alegoria ludzkiego losu). W logice „czarnego" melodramatu niszczenie jest silniejsze niż tworzenie, a to, co dolne lub chtoniczne, ważniejsze niż to, co górne, ukierunkowane wertykalnie, co uwzględniono w projektowaniu przestrzeni scenicznej. Scena finałowa jest utrzymana w barokowej stylistyce, nakładają się na siebie i mieszają antynomie światło-mrok, życie-śmierć: „Teatr przedstawia równinę pustą i dziką, a w głębi morze wzburzone, na którym gdzieniegdzie widać się dają sterczące skały" (Ducange: 114). Rybacy zarzucają sieci, młodzi rybacy tańczą wesoło ze zgromadzonymi na brzegu dziewczętami, wspomniane pogodne scenki tworzą tło akcji głównej. Zgodnie z regułą wahadła mają za zadanie czasowo niwelować napięcie, a następnie spotęgować je, gdy maksymalnie się wychyli i nastąpi oczekiwany efekt hitchcockowski. Nadciąga burza, ryczący żywioł pochłania żarłocznie coraz większe partie lądu, zabiera z sobą dwie ofiary, pozwalając odzyskać martwe ciało kobiety. Struktura zakończenia zgodna jest całkowicie z duchem, choć nie literą Waltera Scotta, w powieści narzeczeni pozostaną rozłączeni fizycznie także w momencie transgresji.

Autor Narzeczonej z Lammermoor również posiłkuje się metaforą - pędzącego na pojedynek Edgara pochłaniają zdradliwe ruchome piaski, wierny sługa wyławia z nich na pocieszenie jedno czarne krucze pióro, ozdobę czapki swojego pana. W ten sposób dzieło będące pierwowzorem i, w jeszcze wyższym stopniu, jego teatralna adaptacja, wpisują się w metaforę świata jako teatru, gdzie ścierają się przeciwstawne siły, walczą zamaskowani przeciwnicy, a jeśli reżyserem jest Bóg, a nie szatan, to występuje on w demiurgicznej odsłonie Deus ridens potęgującej odczucia irracjonalności tudzież przypadkowości życia jednostkowego i zbiorowego. W wersji Ducange’a ogrom zła, przemocy i śmierci, które niespodziewanie wtargnęły w życie sentymentalnie skrojonych, poczciwych bohaterów, zmieniając je w horror, opiera się teorii usprawiedliwienia zakorzenionej w chrześcijańskiej wizji świata. Staranna stylizacja żywych obrazów skondensowanych w kształcie emblematycznego malowidła, stanowiących brutalną egzemplifikację iście manichejskiej, szarpiącej trzewiami wizji ludzkiego losu, jest sui generis sposobem realizacji arystotelesowskiej kategorii patosu.

Dzwonnik z Notre Dame Charlotte Birch-Pfeiffer pozostaje przede wszystkim świadectwem tego, jak kaleki może okazać się melodramat, gdy nie otrze się o poezję wysokich lotów. Autorka znała teatr niejako „od kulis”, przez sześć lat 
była cenioną niemiecką aktorką, pisarką, reżyserką teatru miejskiego w Zurychu, napisała ponad 100 sztuk i librett operowych. Omawiana melodrama adaptuje na scenę powieść Wiktora Hugo Katedra Notre Dame w Paryżu, jednak daleko idące zmiany powodują, że tragiczny potencjał tej historii jawi się w postaci znacznie złagodzonej i umniejszonej. Ocalona zostaje Cyganka Esmeralda, cenę życia płaci za to Quasimodo; jest to typowa śmierć-ofiara, która dokonuje się w imię ocalenia ogólnego dobra i uniwersalnej prawdy. Autor omawianej wcześniej Oblubienicy z Lammermoor umieścił wydarzenia o wysokiej temperaturze emocjonalnej w na wskroś romantycznych dekoracjach, dzięki czemu szaleństwo jest nie tylko efektowne, ale i wiarygodne. Charlotte Birch-Pfeiffer całkowicie zaprzepaściła ów potencjał. Wielkim nieobecnym Dzwonnika z Notre Dame jest tytułowa katedra i inne przestrzenie labiryntowe, takie jak paryskie zaułki i uliczki, tudzież słynny Dziedziniec Cudów. Tym, co udaje się ocalić z pierwowzoru, jest namiętność, którą tchną wyznania odpowiednio Esmeraldy, Phebusa i Frolla; miłość jawi się jako jedyne, ostateczne doświadczenie egzystencjalne, nie zna żadnych hamulców, nie kieruje się rozsądkiem, wiedzie do autodestrukcji. Gdyby nie sentymentalny krój nadany dziełu przez autorkę, z pewnością zginęłaby więcej niż jedna osoba. Wspomniany melodramat sytuuje się kompozycyjnie blisko sztuk w obrazach, choć te ostatnie wchodzą tu jeszcze w rozmaite związki z dramatem traktowanym jako spójne dzieło literackie przeznaczone do wystawienia na deskach teatru. Obserwować to można zwłaszcza w nieco przydługich scenach deklamacyjnych, w których sentymentalni bohaterowie nader chętnie dzielą się stanem swoich serc i umysłów.

Dzwonnik z Notre Dame jest dziełem w sześciu „oddziałach”. Za najważniejsze węzły dramatyczne należy uznać historię dziecka porwanego przez Cyganów z wiernie przejętym od Hugo rozpoznaniem po haftowanym trzewiczku, próbę zamordowania Phebusa przez szaleńczo zazdrosnego Frolla, uwięzienie Esmeraldy oraz nieoczekiwanie odbicie jej przez zakochanego Quasimodo i coup de théâtre $\mathrm{w}$ postaci śmierci zakochanego dzwonnika poniesionej w obronie ukochanej. W strukturze melodramatu występują sceny komplementarne, stanowiące swoje konieczne dopełnienie. Birch-Pfeiffer wyraźnie uwięzła w kleszczach antynomii „od euforii do depresji”, buduje sztukę, wykorzystując szybko następujące po sobie sekwencje o skrajnie odmiennych dominantach emocjonalnych. Wspomniane sceny wykazują sporą autonomię i choć zostały 
powiązane logicznie i tematycznie z intrygą, mogłyby zostać skopiowane do innego melodramatu jako autonomiczne całostki definiowane typem dominującej emocji, np. egzemplifikacja rozpaczy wiodącej ku szaleństwu. Jako przykład może służyć lament oszalałej z bólu matki, której dziecko porwali Cyganie. Oprócz wycia i szarpania szat, miotania się po scenie, ekspresyjnej gestyki sygnalizowanej w didaskaliach jasny obraz drastycznych ubytków we władzy sądzenia dają wypowiadane przez nią słowa - obłąkane fantasmagorie w rodzaju rosnących u ramion skrzydeł, wyartykułowanego (graniczącego z pewnością) przeczucia, że dziewczynka nie żyje, bo została zjedzona bądź jej krew wykorzystano do odmłodzenia bogatych starców. W planie kompozycji prezentacji bólu prowadzącego do utraty zmysłów odpowiada wybuch szaleńczej radości z odzyskania córki, radości, która, co symptomatyczne, niemal natychmiast kontrapunktowana jest ponowną utratą cudownie odzyskanego dziecka. Sceny układają się w sekwencję: rozpacz - euforia - rozpacz. W scenie brutalnego zabójstwa Phebusa przegląda się z kolei jak w zwierciadle mord dokonany na Quasimodo, tym bardziej, że zabójca to jedna i ta sama osoba. Birch-Pfeiffer w interesujący sposób modyfikuje wątek miłosny powieści - Phebus nie jest cynicznym uwodzicielem, który zamierza wykorzystać i porzucić zakochaną Cygankę, zamiast brutalnego odarcia z szat (Hugo) i inicjowanego gwałtu otrzymujemy nieśmiałe pieszczoty i poetyckie melodeklamacje. Interesująca wydaje się fetyszyzacja ciała Esmeraldy. Cyganka ulega uprzedmiotowieniu, uroda i seksapil dziewczyny stają się częścią spektaklu. Jej występ taneczny pojawia się kilkakrotnie w wypowiedziach innych postaci, które nie mogą przyjść do siebie, gdyż ciągle stoi im przed oczami kusicielka wykonująca fandango. Uczucie Phebusa ulega w interpretacji Birch-Pfeiffer daleko idącej idealizacji, pobrzmiewają tu wielkie wzory literackie, jak Burns czy Szekspir:

Ale nie mamże podnieść perty, dlatego że w prochu leży? Nie mamże zerwać róży, dlatego że w prochu zakwitła? Czyż perła nie jest perłą, a róża czyliż przez to mniej ma zapachu?

(Birche-Pfeifer: nlb. [16]).

Zakochany młodzieniec zamierza sprzeciwić się nakazom swojej klasy społecznej i pojąć dziewczynę za żonę, zaś po jej uwięzieniu sprzymierza się z żebrakami, jej dotychczasowymi opiekunami, by pomogli kochankom w ucieczce. Stanowi to całkowite odstępstwo od pierwowzoru - cyniczny uwodziciel spod 
pióra Hugo za nic ma sobie uczucia innych, jego jedynym fetyszem jest własna satysfakcja. Cygankę mógł uwodzić po kryjomu, w przytomności „porządnych” obywateli nigdy się do niej nie przyzna. Jeszcze dalej idącej modyfikacji podlega w sztuce postać kalekiego karła. Quasimodo, odmiennie niż w powieści, budzi w Cygance jedynie współczucie, nie odrazę, melodramatyczna Eseralda intuicyjnie pojmuje prawdę wyrażoną przez Hugo w przejmującej piosence dzwonnika, że piękna powierzchowność kryje często szkaradny charakter, a mimo to piękno i tak kocha się dla piękna. Dzwonnik jest dla niej, co wyraża w ostatnich słowach wypowiedzianych do umierającego, piękną duszą uwięzioną w niegodnej siebie skorupie. Quasimodo w melodramacie występuje, co interesujące, w stroju błazna, „w kurcie z prawej strony czerwonej, z lewej czarnej, w takichże spodniach, a przy każdym zębie mały dzwoneczek” (Birche-Pfeifer: nlb. [13]), który jest znakiem wewnętrznego żaru, braku harmonii, nieuporządkowania. Jego powierzchowność jest idealnie zgodna z pierwowzorem:

[L] ewa noga znacznie dłuższa niż druga, przez co kulawy mocno, garby ma wielkie z tyłu i z przodu, tak że głowa siedzi między garbami, usta szerokie, zęby czarno zalepione jakby był bez zębów, usta szerokie, jedno oko cielistą florą zakryte, brwi szczególnego kształtu czerwone, i włosy kędzierzawe czerwone.

(Birche-Pfeifer: nlb. [21])

Wydaje się, że autorce szczególnie zależy na epatowaniu scenicznym kontrastem Pięknej i Bestii.

Esmeralda i Quasimodo to jedyne postacie, których wygląd szczegółowo opisano tak w kwestiach innych postaci, jak i didaskaliach; co zastanawiające, dominantą jest tu kolor czerwony. Melodramat Birch-Pfeiffer relatywnie słabo wykorzystuje możliwość pogłębienia opisu osób działających i przestrzeni scenicznej przez użycie metafory. Czerwień, obok wspomnianego wewnętrznego „ognia”, wpisuje się w porządek przelanej krwi, zapowiadanych, symbolizowanych i spełnionych gwałtownych wypadków; w więzieniu Esmeralda majaczy: „weźcie ode mnie wasze zbroczone krwią ręce” (Birche-Pfeifer: nlb. [21]). We wspomnianej scenie słuchać odległe echa Szekspirowskie (Lady Makbet). W wypadku organizacji przestrzeni scenicznej Dzwonnika z Notre Dame na uwagę zasługuje konsekwentne podkreślanie tożsamości więzienia i grobu jako przestrzeni śmierci, klaustrofobicznej, zimnej, dla człowieka pierwotnie obcej, bo 
separującej od innych, od powietrza, światła, przyrody. Symboliczne wydaje się, że umierającego dzwonnika żegna dźwięk dzwonu, jedyny, jaki mógłby usłyszeć.

Ostatni melodramat, Switezianka, „z ocaleniem niektórych miejsc ballady Mickiewicza”, „oryginalnie” napisany przez Franciszka Rynkiewicza, stanowi literackie curiosum, jest utworem drażniącym i śmiesznym. Utwór został oparty na dwóch konfliktach dramatycznych, które praktycznie wcale się nie zazębiają, zostały „sfastrygowane” bardzo grubą nicią. Ważniejszy z nich, co sugerowałby tytuł, odtwarza wiernie balladę Mickiewicza, z tym zastrzeżeniem, że wystawiająca młodzieńca na próbę nimfa nie ogranicza się do jednej tylko zmiany roli. Występuje w postaciach Wieśniaczki, Strzelca, Wyroczni, Barda, Muzykanta wiejskiego i Podróżnej damy. Przypomina to rozwiązania komediowe spopularyzowane przez Ludwika Adama Dmuszewskiego w komedii Siedem razy jeden, a zaczerpnięte z praktyki intermedialnej lub dellartowskiej. W tym przedziwnym konglomeracie gatunkowym, jaki stanowi ta sztuka, pomieszaniu typów bohaterów towarzyszy pomieszanie stylów. Drugi konflikt nosi znamię tragicznego - właściciel zamku, w pobliżu którego toczy się akcja, Tuhan, obciążony jest straszną zbrodnią, rozkazał bowiem swojemu poufałemu Kurdeszowi zabić w niemowlęctwie przyrodniego brata, który mógłby w przyszłości aspirować do równego podziału majątku. Cudownie ocalonym od śmierci w bagnie dzieckiem okazuje się strzelec Stanisław, ukochany Świtezianki, która doprowadza do rozpoznania i ujawnienia sprawcy zbrodni. W wypadku Świtezianki Rynkiewicza najbardziej krwawym czynem jest próba sklasyfikowania jej jako melodramat. Choć autor wyraźnie odczuwał rozdroże literackich kierunków i stylów, na jakim się znalazł, tym niemniej wykazał się genologiczną i onomastyczną bezradnością, by nie powiedzieć - impotencją. Wspomniany utwór najbezpieczniej byłoby klasyfikować jako komediooperę, czyli wodewil.

Co zatem skłania autora do stwierdzenia, że napisał melodramat? Wydaje się, że preferowany typ wyobraźni. Tuhan jako postać mógł zaspokajać tęsknotę dramatopisarzy za nieprzeciętną indywidualnością, gdyż jest bezwzględnym, wręcz oszalałym mordercą, nierozstającym się ze sztyletem; nie odczuwa najmniejszej skruchy, jego jedynym pragnieniem, jak sam zaklina na piekielne potęgi, jest własnoręczne dopełnienie bratobójczego czynu. Zapamiętuje się w nienawiści, którą odczuwa, jak sam przyznaje, bez żadnej racjonalnej przyczyny, bo trudno za taką uznać zdobycie przez brata względów nimfy wodnej. 
W konsekwencji ściągnie na siebie śmierć, pochłonięty jednym tylko pragnieniem zatopienia sztyletu w piersi brata, biegnie za nim i wpada do wodnej kipieli jeziora. Upodobanie autora do frenezji w duchu romantycznym zdradza scena stanowiąca zapowiedź finałowych, tragicznych wydarzeń. Kurdesz, współwinny Tuhana w zbrodni, zawisł na stryczku w tym samym czasie, gdy były właściciel zamku opuścił swoje włości, gdyż pojednanie z bratem, o które zabiegał sam skrzywdzony Stanisław, jawiło się możnowładcy jako niemożliwe do zaakceptowania. Błąkając się jak żebrak po lesie położonym w sąsiedztwie bezpowrotnie utraconej siedziby rodowej, natknął się na rozkładające się zwłoki swojego sługi i posłusznego wykonawcy zbrodni. Cuchnące truchło na krótką chwilę budzi jego sumienie, z punktu widzenia kompozycji melodramatu ważniejsze wydaje się wszakże, jak autor, wyraźnie zapatrzony w dzieła inspirowane duchem frenezji czarnoromantycznej, nieudolnie próbuje nadać swojemu dziełu modny kształt stylistyczny:

Jego to cielsko obrzydłe

Zarażone brzydkim trądem

Powietrze zatruwa wokół

Nieprzyjemnym trupa swądem

Nie tknął by go nawet sokół

Patrzcie jak nim wiatr pomiata

Taka to zbrodni zapłata.

(Rynkiewicz: nlb. [18])

Sygnalizowane w tytule melodramatu Rynkiewicza ocalenie niektórych miejsc ballady polega w praktyce na dokładnym przepisaniu wszystkich fragmentów dialogowych przy całkowitym pominięciu partii narratora.

Jednak nie to powoduje największe rozdrażnienie czytelnika. Postaci Strzelca i Świtezianki tracą swoją baśniowo-magiczną prostotę i jednoznaczność przy próbie pogłębienia ich charakterów. Wodna boginka, która przynajmniej dwa razy zdradza swoje nietypowe pochodzenie, ukazując się odziana od pasa w dół rybią łuską, wydaje się na pierwszy rzut oka bardzo troszczyć o Strzelca. Chroni go przed morderczymi zakusami brata, doprowadza do zwrócenia mu rodzinnego majątku. W tym samym wszakże momencie neguje fakt, że bogactwo może dać człowiekowi szczęście, co najwyżej wystawia go na więcej pokus. Wydaje się pochłonięta obsesją zdrady, cały czas spędzany przez kochanków, 
a są to ulotne chwile, wypełniają jej przestrogi, fałszywe domniemania i groźby. Świtezianka pojawia się i odchodzi bez zapowiedzi, powraca w dziwacznym przebraniu, daje się rozpoznać, po czym znowu znika. W przestrzeni omawianego dramatu drastycznie brakuje odpowiednika Mickiewiczowskiej frazy „ona mu z kosza daje maliny, on jej różyczki do wianka”, wzajemnego zaufania, ciepła $\mathrm{i}$ intymności.

Strzelec Rynkiewicza jest postacią wyraźnie pękniętą, jego pierwszym deklamacjom miłosnym brakuje „ognia”, nie zaklina się na piekielne potęgi w świetle księżyca, ale o brzasku dnia przysięga na... wodę i wiatr:

Patrz pierwsze promienie słońca

Co w krysztale jezior toną

$\mathrm{Na}$ wody, co płyną i wiatry, co wioną

[...]

Są świadkami mej przysięgi

Żem ci jest wierny bez końca.

(Rynkiewicz: nlb. [5])

Jeśli nawet $\mathrm{w}$ poetyce kalinowego erotyku rytm fal jest rytmem serca, to płynąca woda i wiatr nigdy nie były symbolem trwałości i niezmienności (panta rhei). Wybranek zdradza zresztą mimowolnie w tejże samej scenie, jak lekce sobie waży złożone przed momentem obietnice:

Ach, próżne wzbudzasz obawy!

Mógłbym tysiąc razy przysiąc

I dochować razy tysiąc

Użyjmy chwilę zabawy.

(Rynkiewicz: nlb. [5])

Świtezianka przez mieszkańców zamku Tuhana i jego samego jest postrzegana bardziej jako widmo czy diablica niż dobroczynna siła natury. Stanisław spędza życie na daremnym oczekiwaniu na swoją bogdankę, zabija czczość i nudę rozmyślaniem o wiecznej miłości. Ma przeczucie nieokreślonego zagrożenia, w jednym z najsubtelniejszych fragmentów sztuki słabej tak kompozycyjnie, jak i stylistycznie, porównuje swoją sytuację egzystencjalną do motylka, który

niepewny, ściągając lotem

czepia się pod róży listkiem 


\author{
nie wie, że go czeka strata \\ bo kwiat ociężon kropelki \\ chłodnej porankowej rosy \\ gdy zefirek tylko wionie \\ zerwanym pączkiem od kwiata \\ nieszczęśliwego przygniata \\ (Rynkiewicz: nlb. [38])
}

W istocie Strzelec ginie nieco przypadkowo, co prawdopodobnie wynika z nieporadności autora. Jego racje, czy to z powodu niewystarczającego przekonania, czy żałośnie marnej egzemplifikacji poetyckiej spod pióra Rynkiewicza, pozostają „na papierze”. Wydaje się prawdopodobne, że autor chciał poprowadzić swoją postać w kierunku człowieka, który nie potrafi kochać, a tylko mówić i marzyć o miłości. Wyimaginowana bańka poznawcza fundowana na wierze w Platoński świat idei pryska w pierwszym zetknięciu z rzeczywistością. Strzelec, olśniony wdziękami Przyjezdnej damy, odkrywa, że pragnie obcować z żywym ciałem, a nie fantazmatem. W nieoczekiwanie zabawnej scenie, całkowicie à rebours intencji autora, gotów jest z nieprzystojnym pośpiechem konsumować jej wdzięki w lesie, gdy przebrana Świtezianka udaje omdlenie związane z domniemanym napadem zbójców. W obrębie dość krótkiej sztuki, wahającej się rozmiarem między dwoma a trzema aktami, Świtezianka wystawia swojego wybranka na próbę siedem razy. Czytelnik czuje ulgę, gdy Strzelec, któremu ciągle grożono, jeśli akurat go nie kuszono, wreszcie ulega pokusie. Omawiany melodramat ma miejsca o mocniejszej dyspozycji dramatycznej, są nimi całkiem udatne sceny komediowe z udziałem sług Tuhana - Sokolnika Skrzydełko, więźnia Szyldwacha, Glinki i Chwałki, a zwłaszcza klucznicy Małgorzaty - w postaci dynamicznych dialogów powiązanych z wątkiem damsko-męskiej walki o przywództwo w domu czy monologu o tym, jak krótko należy trzymać męża. Świtezianka posiada rozbudowane partie muzyczne w najmniejszym stopniu niepowiązane z dwoma głównymi wątkami. Sceny w typie komiki niskiej - awantury o jedzenie, łapczywe wypijanie wina, dysputy wyznawców filozofii „lekkiego chleba” - występowały również w pierwszym z omawianych i - jak starałam się udowodnić - najbardziej spójnym ideowo i stylistycznie melodramacie. 
Grupa omówionych powyżej melodramatów „przepisywanych” z tekstów różnogatunkowych obejmuje utwory zarówno wtórne i literacko ubogie, jak i ciekawe, można by rzec, nowatorskie. Co najistotniejsze, granice między zależnością a własną inicjatywą twórczą bywają rozmyte, trudne do uchwycenia. W okresie, gdy powstawały, trudnym do sklasyfikowania w porządku następstwa epok historycznoliterackich, zapożyczenie tematu nie zaprzeczało niezawisłości dzieła. Omawiane melodramaty zachowują więź z utworem inicjującym, wyrażoną choćby przez wybór tytułu, niemniej jednak wzbogacanie ich o treści wcześniej nieistniejące wydaje się obarczone pragnieniem wykrystalizowania własnej tożsamości twórczej, sytuującej się nierzadko w obrębie obszaru kultury popularnej, gdzie ostatecznie liczy się palimpsestowość, „przezroczystość” form ułatwiająca „nadpisanie” treści rozrywkowych lub ideologicznych. Wszystkie wspomniane dramaty wpisują się, lepiej lub gorzej, w typowy dla gatunku schemat fabularny, tematyczny i aksjologiczny kreujący manichejską wizję świata opartego na gwałcie. Znajdziemy w nich nierzadko przeciwstawne kompleksy ideowe i światopoglądowe: sentymentalizm i dworską dyscyplinę uczuć, tradycjonalizm i eudajmonistyczne dążenia emancypującego się rozumu, fetyszyzację wolności osobistej i moralizatorski kult cnoty, optymizm i fatalizm, patos graniczący z żywiołem farsowej zabawy. Napięcia, sprzeczności i niespójności zostają w ostatecznym rezultacie w melodramatach Ducange'a i Birche-Pfeifer przetworzone w harmonijną całość. Zawiera się w nich ogólne przesłanie o konieczności afirmacji nieuchronnych sprzeczności i paradoksów życia, konstytuowane niejako wbrew wymowie scenicznych wydarzeń, których siłą napędową są konflikty wynikające z przeciwstawnych dążeń i wykluczających się wartości. Wydaje się więc poniekąd naturalne, że terenem wytężonej eksploracji stały się dwa kanoniczne teksty przedstawiające swoich bohaterów poddanych panoramicznemu oglądowi w mocno nacechowanej emocjonalnie przestrzeni, jak w prozie Scotta i Hugo, w której następuje polaryzacja świata, a poszczególne postaci stają się wiernymi odbiciami krańcowych wartości aksjologicznych. 


\section{Bibliografia}

Birche-Pfeifer, Karolina. Dzwonnik z Notre Dame. Dramat w 6 oddziatach. Tłum. Szczęsny Starzewski. B.m., 1850. Rkps. Zakładu Narodowego im. Ossolińskich 10568.

Brooks, Peter. The Melodramatic Imagination: Balzac, Henry James. Melodrama and the Mode of Excess. New Haven: Yale University Press, 1995.

Connor, Steven. „Rewriting Wrong: On the Ethics of Literary Reversion”. Liminal Postmodernisms: The Postmodern, the (Post-)Colonial, and the (Post-)Feminist. Red. Theo D'haen, Hans Bertens. Amsterdam-Atlanta: Rodopi, 1994.

Ducange, Victor. Oblubienica z Lammermoor. Melodrama heroiczna $w$ trzech aktach. Tłum. Teresa Palczewska. Warszawa: Drukarnia A. Gałęzowskiego i Komp., 1832.

Leyko, Małgorzata. „Teatr jako sztuka (systemowego) przepisywania”. Zagadnienia Rodzajów Literackich 2 (2014): 77-88.

Martuszewska, Anna. Architektonika literackiego romansu. Gdańsk: słowo/ obraz terytoria, 2014.

Nycz, Ryszard. „Poetyka intertekstualna: tradycje i perspektywy”. Kulturowa teoria literatury. Gtówne pojęcia i problemy. Red. Michał Paweł Markowski, Ryszard Nycz. Kraków: Universitas, 2010: 153-180.

Ratajczakowa, Dobrochna. „Melodrama”. Galeria gatunków widowiskowych, teatralnych $i$ dramatycznych. Poznań: Wydawnictwo Naukowe Uniwersytetu im. Adama Mickiewicza, 2015.

Rynkiewicz, Franciszek B. Świtezianka. Melodramat w 3 aktach wierszem romantycznym z ocaleniem niektórych miejsc ballady Mickiewicza oryginalnie napisana. B.m. B.r. Rkps Zakładu Narodowego im. Ossolińskich 9922.

Scott, Walter. Narzeczona z Lammermoru. T. 3. Tłum. Franciszek Salezy Dmochowski. Warszawa: Drukarnia Gazety Korespondenta, 1828.

Słowacki, Euzebiusz. Dzieła. T. 5. Wilno: Nakład i druk Marcinkowski, 1827. 


\title{
Melodrama as a "Rewritten" Genre (on the Example of the $19^{\text {th }}$ Century Dramas Inspired by the Works of Hugo, Mickiewicz, Scott)
}

\begin{abstract}
Summary
The article is devoted to intertextuality in the nineteenth-century dramatic texts inspired by other literary forms. The group of melodramas rewritten from texts of various literary genres includes works both secondary and literally impoverished, as well as some that are interesting, even innovative. In the practice of rewriting, the main plot of the original is retained only in its general outlines. The omissions, rearrangements, and simplifications often associated with a complete change in the sense of the prototype seem to be particularly interesting; although inspirations from sentimentalism are extremely important. The melodramas in question retain a link with the original work expressed not only by the choice of title but also by enriching them with content that did not exist before. This seems to be an effort to crystallize their own creative identity, often falling within the realm of popular culture.
\end{abstract}

Keywords: melodrama, theatre, rewriting, sentimentalism, $19^{\text {th }}$ century

Słowa kluczowe: melodramat, teatr, przepisywanie, sentymentalizm, XIX wiek 